\author{
EUGENIUSZ RYDZ, PAULINA BARAŃSKA \\ Wyższa Szkoła Pedagogiczna, Słupsk
}

\title{
Wybrane problemy przemysłu mleczarskiego województwa słupskiego w latach 1990-1996
}

W polskiej gospodarce przetwórstwo spożywcze zajmuje szczególną pozycję, gdyż jest to nadal najważniejsza gałąź naszego przemysłu. Jego udział w produkcji sprzedanej całego przemysłu wynosił w 1996 r. 20,7\%. Wyroby przemysłu spożywczego stanowiły około $32 \%$ sprzedaży towarów na rynek wewnętrzny i 10\% eksportu. Przemysł spożywczy stanowi zatem ważne ogniwo gospodarki narodowej, w tym szczególnie gospodarki żywnościowej kraju. Główne zadania przemysłu spożywczego w gospodarce żywnościowej można ująć następująco:

- przyjęcie produkcji towarowej od rolnictwa do zakładów przetwórczych,

- utrwalenie i magazynowanie żywności,

- przetwarzanie i uszlachetnianie żywności,

- wytwarzanie produktów spożywczych.

Przetwórstwo spożywcze, podobnie jak wiele dziedzin gospodarki w okresie transformacji systemowej, przeobraża systematycznie swoją strukturę ekonomiczną i organizacyjną, zachowując przy tym jemu tylko właściwą specyfikę. W świetle powyższych uwag celem naszego artykułu jest przedstawienie wybranych problemów funkcjonowania przemysłu mleczarskiego na terenie województwa słupskiego w latach 1990-1996 oraz jego powiązania z bazą surowcową.

Podstawowym czynnikiem determinującym wielkość produkcji mleka jest stan pogłowia krów. Od początku lat 90. obserwuje się na terenie województwa słupskiego drastyczny jego spadek - z 55786 sztuk w roku 1990 do 24950 sztuk w roku 1996, tj. o około $56 \%$ (tab. 1). W tym samym okresie bardzo wyraźnie zmniejszyło się pogłowie bydła na 100 ha użytków rolnych - z 42 sztuk (w 1990 r.) do 21 (w 1996 r.) przy średnim spadku w skali kraju odpowiednio z 54 do 40 sztuk. Podkreślić należy, że spadek ten dotyczył przede wszystkim pogłowia należącego do państwowych gospodarstw rolnych i był efektem wycofania się państwa z szeregu dotacji do produkcji rolnej oraz konieczności spłaty zobowiązań finansowych wobec pracowników i banków, a w ostateczności bankructwa PGR-ów.

Zdecydowana większość stada krów w momencie likwidacji gospodarstw została przeznaczona na ubój, pozostałą część zakupili rolnicy indywidualni lub przejęli zarządcy 
nowo utworzonych spółek i innych podmiotów powstałych na bazie zlikwidowanych PGRów. Przemiany gospodarcze lat 90. przyspieszyły również proces zmniejszania się pogłowia krów, także z powodu niskiej opłacalności produkcji mleka.

Tabela 1. Stan pogłowia krów w województwie słupskim w latach 1990-1996

\begin{tabular}{|l|c|c|c|c|c|}
\hline \multirow{2}{*}{ Rok } & \multicolumn{4}{|c|}{ Pogłowie krów (szt.) } & $\begin{array}{c}\text { Pogłowie krów } \\
\text { na 100 ha UR } \\
\text { (szt.) }\end{array}$ \\
\cline { 2 - 5 } & Ogółem & $\begin{array}{c}\text { Gospodarstwa } \\
\text { państwowe }\end{array}$ & $\begin{array}{c}\text { Gospodarstwa } \\
\text { indywidualne }\end{array}$ & $\begin{array}{c}\text { Inne } \\
\text { jednostki }\end{array}$ & 16,9 \\
\hline 1990 & 55786 & 24189 & 31597 & 151 & 14,4 \\
\hline 1991 & 47554 & 19483 & 27938 & 133 & 11,8 \\
\hline 1992 & 38996 & 13120 & 25714 & 162 & 10,1 \\
\hline 1993 & 33495 & 8202 & 25215 & 78 & 8,8 \\
\hline 1994 & 27951 & 3723 & 23029 & 1199 & 8,4 \\
\hline 1995 & 27915 & 1895 & 23910 & 2110 & 7,7 \\
\hline 1996 & 24950 & 1527 & 20928 & 2495 & \\
\hline
\end{tabular}

Źródło: Roczniki Statystyczne woj. słupskiego za lata 1991, 1993, 1995

Informacja o sytuacji gospodarczej województwa stupskiego w 1996 r., Urząd Statystyczny, Słupsk 1997

Proces zmniejszania się pogłowia krów nie został jeszcze całkowicie wyhamowany, choć na podstawie wyników osiąganych przez istniejące gospodarstwa, jak też pewnych przedsięwzięć organizacyjnych można sądzić, że swoje ekstremum już osiągnął i nastąpi pewna stabilizacja. Dzięki powstawaniu znacznej liczby gospodarstw wielkoobszarowych stała się bowiem możliwa w wielu przypadkach odbudowa hodowli i większe zmechanizowanie technologii produkcji mleka.

Podkreślić należy, że rozmieszczenie przestrzenne hodowli bydła na terenie województwa słupskiego wykazuje wyraźne zróżnicowanie (ryc. 1). W 1990 r. dość wysokim wskaźnikiem pogłowia charakteryzowały się gminy położone w północnej części województwa (Wicko, Sławno, Główczyce, Nowa Wieś Lęborska). Zjawisko to było wynikiem silnej koncentracji rolnictwa państwowego w pasie nadmorskim, dysponującego dużą ilością stanowisk inwentarskich. Obszary północne województwa posiadają na ogół stosunkowo najlepsze warunki naturalne dla rozwoju hodowli wyrażające się między innymi dużym udziałem łąk i pastwisk w ogólnej powierzchni użytków rolnych, np. 57,6\% w gminie Wicko, 60,7\% w gminie Smołdzino i 38,2\% w gminie Główczyce. Najniższą obsadą bydła na 100 ha użytków rolnych cechowały się położone na Pojezierzu Miastecko-Bytowskim gminy: Koczała, Lipnica, Tuchomie, Miastko, Kępice, gdzie z kolei dominowały rozdrobnione gospodarstwa indywidualne, ze stosunkowo niewielkim odsetkiem powierzchni użytków zielonych (średnio 16\%). Na tym obszarze również spadek pogłowia był mniej drastyczny niż to miało miejsce w przypadku terenów nadmorskich, gdyż w części północnej

i południowej województwa wynosił on na przestrzeni lat 1990-1996 około 50\% w Przechlewie i Damnicy, 60\% w Słupsku, a nawet 70\% w Czarnym (ryc. 2, 3). 
Ryc. 1. Obsada bydła na 100 ha UR.

w gminach województwa słupskiego w 1990 roku

Ryc. 2. Obsada bydła na 100 ha UR

w gminach województwa słupskiego w 1996 roku 
Ryc. 3. Zmiany w obsadzie bydła na 100 ha UR.

w gminach województwa słupskiego w latach 1990-1996

Tabela 2. Produkcja i skup mleka w województwie słupskim w latach 1990-1996

\begin{tabular}{|c|c|c|c|c|}
\hline \multirow{2}{*}{ Rok } & \multirow{2}{*}{$\begin{array}{c}\text { Produkcja } \\
\text { mleka (mln l) }\end{array}$} & \multicolumn{3}{|c|}{ Skup mleka (w tys. litrów) } \\
\cline { 3 - 5 } & & $\begin{array}{c}\text { Ogólnie } \\
\text { województwo }\end{array}$ & $\begin{array}{c}\text { Sektor } \\
\text { publiczny }\end{array}$ & $\begin{array}{c}\text { Sektor } \\
\text { prywatny }\end{array}$ \\
\hline 1990 & 192,5 & 121096 & 61636 & 59460 \\
\hline 1991 & 126,3 & 76524 & 35435 & 41089 \\
\hline 1992 & 119,3 & 59821 & 21599 & 38222 \\
\hline 1993 & 100,7 & 49219 & 16302 & 32917 \\
\hline 1994 & 90,2 & 38019 & 7245 & 30774 \\
\hline 1995 & 84,3 & 39365 & 4895 & 34470 \\
\hline 1996 & 86,7 & 41639 & 2850 & 38789 \\
\hline
\end{tabular}

Źródło: por. tab. 1. 
Zmiany w pogłowiu bydła, a szczególnie drastyczne zmniejszenie się pogłowia krów, spowodowały w latach 1990-1996 na terenie województwa słupskiego także bardzo duży spadek produkcji mleka. W rezultacie po raz pierwszy po wojnie w woj. słupskim pojawiły się niedobory mleka i jego przetworów. Obecnie deficyt ten jest pokrywany dodatkowymi zakupami z innych regionów (tab. 2).

O ile w 1990 r. na terenie prezentowanego województwa wyprodukowano łącznie w rolnictwie indywidualnym i w gospodarstwach państwowych przeszło 192 mln litrów mleka, to na koniec 1995 r. produkcja zmalała do 84,3 mln litrów, tj. 43,7\% stanu z końca 1990 r. Pewne niewielkie ożywienie w skupie mleka, wyrażające się wzrostem o 2,8\%, zanotowano w 1996 r. Największy bezwzględny spadek odnotowano w roku 1991 (o $34,4 \%$ w stosunku do roku poprzedniego), co było między innymi wynikiem nałożenia się na siebie wielu niekorzystnych zjawisk: wpływu złych warunków atmosferycznych na całą produkcję rolna, nagłego zaniechania pomocy państwa dla rolnictwa uspołecznionego, bardzo wysokiej inflacji uniemożliwiającej racjonalne inwestowanie oraz braku odpowiedniego, zaplanowanego czasu przystosowania się jednostek rolnictwa uspołecznionego do nowych

warunków ekonomicznych.

Z przeprowadzonych badań wynika, że na ogólną roczną produkcję mleka skup nie obejmował około 40-60 mln litrów, które pozostawało w gospodarstwach, gdyż ta wielkość była przeznaczona głównie na cele paszowe (karmienie cieląt) oraz na potrzeby własne gospodarstw domowych rolników. Pewien wpływ na mniejszą ilość mleka objętego na początku lat 90. skupem wywarł fakt, że $\mathrm{w}$ tym właśnie czasie rozwinął się w miastach handel obwoźny mlekiem szacowany w 1992 r. na około 14,7 mln 1 i w 1994 r. na około 5,7 mln 1 (Program restrukturyzacji...). Pozostała część mleka nie zagospodarowana przez rolników była skupowana przez 6 zakładów mleczarskich (Słupsk, Lębork, Sławno, Miastko, Bytów, Człuchów) oraz powstałe w latach 90. dwie małe spółki zajmujące się przetwórstwem mleka (Zakład Przetwórstwa Mleczarsko-Mięsnego „Mlekpol” Sp. z o.o. w Dobieszewie

i „Spółkę Mleczną” z o.o. w Pobłociu (ryc. 4).

Każdy z zakładów zajmujących się przetwórstwem mleka rozwinął sieć własnych, stałych punktów skupu, które pozyskują produkt na określonym dla siebie terenie. Pewna rejonizacja skupu dla poszczególnych zakładów jest jeszcze wynikiem polityki rolnej prowadzonej w czasach gospodarki centralnie planowanej, gdy punkty skupu przyporządkowywano poszczególnym zakładom kierując się kryterium najbliższej odległości punktu od mleczarni oraz wielkością ich zapotrzebowania na mleko.

W 1990 roku funkcjonowało w woj. słupskim 137 punktów prowadzących skup mleka, przy czym największą ich ilość posiadały mleczarnie w Słupsku (34), Człuchowie (32) i Miastku (27). Mleczarnie te miały na ogół dogodne usytuowanie w terenie, pozwalające obją́ swym zasięgiem duże obszary województwa. Mniejszą ilość punktów skupu mleka posiadały nieduże mleczarnie położone na obrzeżach województwa: Lębork (19), Bytów (19), Sławno (6), które jednak w pehni zaspokajały ich niewielkie moce przerobowe (Program restrukturyzacji...). Do 1994 r. w wyniku dużego spadku produkcji mleka zlikwidowano ogółem 13 punktów skupu. Zmalał również

o 60\% w stosunku do 1990 r. skup mleka. W dalszym ciagu likwidowane są nierentowne punk- 
ty o najniższym poziomie skupu oraz punkty prowadzące skup przez dojeżdżające autocysterny (Owsiany 1997).

Ryc. 4. Rejony skupu mleka zakładów mleczarskich województwa słupskiego

Wynikiem procesu transformacji gospodarki stało się powstanie nowego, całkowicie przeobrażonego sektora przetwórstwa rolnego. Charakterystyczne dla całego kompleksu żywnościowego przemiany szczególnie szybko i wyraźnie przebiegały w sektorze przetwórstwa mleka. Sektor ten był oparty głownie na spółdzielczym, niesamodzielnym zarzą- 
dzaniu i gospodarowaniu nie wymuszającym żadnej konkurencji (rządowe ceny na skupowane mleko i wyprodukowane wyroby). Cechowała go także duża wrażliwość na wszelkie zmiany w ilości skupowanego mleka (mniejszy skup nie zaspokajał mocy przerobowych zakładów, wskutek czego pogarszały się wskaźniki rentowności produkcji) oraz silna zależność wielkości produkcji od popytu na rynku (nagłe zmniejszenie popytu spowodowało duże perturbacje w określeniu profilu produkcji). Zmniejszył się również - wg szacunków Instytutu Ekonomiki Rolnictwa i Gospodarki Żywnościowej - o około 20\% poziom spożycia przetworów mlecznych.

Sektor przetwórstwa mleka w woj. słupskim miał na początku lat 90. szczególnie niekorzystne warunki rozwoju w porównaniu z innymi regionami Polski. Obok pewnego szoku, którym było niewątpliwie dla każdej jednostki w kraju uwolnienie cen i zlikwidowanie dopłat państwowych, zakłady mleczarskie w ciagu trzech lat utraciły blisko $2 / 3$ wielkości skupu mleka.

Pozbawienie się tak dużej części skupu wynikało głównie z jednostronnego ukierunkowania się na nabywanie mleka od PGR-ów, które ulegając bankructwu całkowicie załamały rynek skupu mleka i pozbawiły zakłady mleczarskie szans na wzrost skupu w najbliższych latach. 
Ryc. 5. Miejscowości największych zakupów mleka przez „Nestle” Polska - Fabrykę w Słupsku

Tabela 3. Miejscowości największych zakupów mleka przez Nestle Polska - Fabrykę w Słupsku w 1995 r.

\begin{tabular}{|c|c|c|c|c|c|}
\hline \multirow{2}{*}{$\begin{array}{l}\text { Miejsce wg } \\
\text { ilości zakupu }\end{array}$} & \multirow[t]{2}{*}{ Miejscowość } & \multicolumn{3}{|c|}{ Zakup mleka (w l) } & \multirow{2}{*}{$\begin{array}{l}\text { Przybliżona } \\
\text { odległość od } \\
\text { Słupska }(\mathrm{km})\end{array}$} \\
\hline & & Ogółem & Pełne & Chude & \\
\hline 1. & Ciechanów & 7932494 & 1319160 & 6613334 & 440 \\
\hline 2. & Lipno & 6884080 & 0 & 6884080 & 305 \\
\hline 3. & Żuromin & 2985650 & 2048650 & 936600 & 390 \\
\hline 4. & Działdowo & 1603560 & 169980 & 1433580 & 341 \\
\hline 5. & Szczecinek & 1427033 & 0 & 1427033 & 105 \\
\hline 6. & Sierpc & 772050 & 526800 & 245250 & 340 \\
\hline 7. & Aleksandrów K. & 561871 & 78466 & 483405 & 300 \\
\hline 8. & Włocławek & 447900 & 0 & 447900 & 330 \\
\hline 9. & Sępólno Kraj. & 421000 & 60200 & 360800 & 152 \\
\hline 10. & Wagrowiec & 413300 & 0 & 413300 & 241 \\
\hline 11. & Zambrów & 358700 & 0 & 358700 & 540 \\
\hline 12. & Koło & 341750 & 0 & 341750 & 355 \\
\hline 13. & Płońsk & 308530 & 166730 & 141800 & 400 \\
\hline 14. & \begin{tabular}{|l|} 
Miastko \\
\end{tabular} & 304798 & 0 & 304798 & 59 \\
\hline 15. & Szczecin & 287450 & 287450 & 0 & 206 \\
\hline 16. & \begin{tabular}{|l} 
Międzyrzecz \\
\end{tabular} & 282500 & 36250 & 246250 & 333 \\
\hline 17. & Rypin & 262350 & 0 & 262350 & 338 \\
\hline 18. & Pasłęk & 248850 & 0 & 248850 & 226 \\
\hline 19. & Gryfice & 205600 & 0 & 205600 & 150 \\
\hline 20. & \begin{tabular}{|l} 
Pyrzyce \\
\end{tabular} & 194400 & 158900 & 35500 & 234 \\
\hline 21. & Bytów & 160896 & 160896 & 0 & 60 \\
\hline 22. & Dobre & 123640 & 0 & 123640 & 320 \\
\hline 23. & Mogilno & 123100 & 0 & 123100 & 270 \\
\hline
\end{tabular}

Źródło: Dział zakupu surowca Fabryki „Nestle” Polska w Słupsku

Malejąca siła nabywcza ludności woj. słupskiego (niższa o ok. 30\% od średniej krajowej) stworzyła dodatkową barierę popytu prowadzącą do ograniczania produkcji. W związku z tym obniżyło się wykorzystanie zdolności produkcyjnych zakładów mleczarskich, a zarazem wzrost kosztów stałych na jednostkę produktu finalnego. W przypadku spółdzielczych zakładów, na których opierało się przetwórstwo mleka w województwie, było to o tyle niekorzystne, gdyż jeszcze przed urynkowieniem gospodarki charakteryzowały się one wysokimi na ogół kosztami przetwórstwa. Składały się na nie wysokie koszty utrzymania punktów skupu, przestarzałe technologie powodujące duże zużycie w procesie produkcyjnym wody, energii i robocizny. W efekcie nałożenia się tych czynników nastąpił stopniowy spadek rentow- 
ności w przemyśle mleczarskim (z 11,1\% w 1989 r. do 1,04\% w 1991 r.) (Program restrukturyzacji...).

Paradoksalnie kryzys mleczarstwa w początku lat 90. pogłębiło oddanie do użytku nowego obiektu Słupskiej Spółdzielni Mleczarskiej w Kobylnicy, mającego pełnić rolę głównego producenta przetworów mlecznych w regionie słupskim. Zdolność przetwórcza tego zakładu wynosiła 380 tys 1 mleka na dobę, podczas gdy w 1992 r. przerabiano jedynie 170 tys. 1 mleka na dziennie (Rydz, Jażewicz 1994). Z powodu braku surowca w województwie zakład ten, dysponujący blisko połową mocy przerobowej mleka w woj. słupskim, zmuszony został do sprowadzania nadwyżek występujących w innych regionach kraju, np. z województw: ciechanowskiego, włocławskiego, bydgoskiego (tab. 3, ryc. 5).

Podkreślić należy, że udział tych zakupów w ogólnym przerobie mleka wzrósł od 4,8\% w roku 1990 do 59,3\% w roku 1995. Taka metoda uzupełniania niedoborów mleka jest możliwa tylko w przypadku tego dużego zakładu mającego dobrze rozwiniętą bazę transportową oraz duże możliwości zbytu wyprodukowanych wyrobów (Zakład Mleczarski w Kobylnicy należy od 1993 r. do szwajcarskiego koncernu spożywczego „Nestlé”).

Proces urynkowienia gospodarki spowodował bardzo istotne zmiany w strukturze produkcji wyrobów mlecznych. Przy ograniczonych możliwościach nabywczych ludności, narastającej konkurencji silnych pozalokalnych zakładów mleczarskich, otwarciu rynku i trudnościach ekonomicznych mleczarni nastąpił duży ogólny spadek produkcji (tab. 4, ryc. 6).

Tabela 4. Produkcja wybranych wyrobów mleczarskich w województwie słupskim

\begin{tabular}{|l|c|c|}
\hline \multicolumn{1}{|c|}{ Rodzaj produktu } & $\begin{array}{c}\text { Wielkość produkcji } \\
\text { w 1990 r. }\end{array}$ & $\begin{array}{c}\text { Wielkość produkcji } \\
\text { w 1995 r. }\end{array}$ \\
\hline Mleko (w tys. litrów) & 26758,1 & 13487,7 \\
\hline Śmietana (w tys. litrów) & 1553,6 & 2415,7 \\
\hline Masło (w tonach) & 2507 & 531 \\
\hline Twarogi (w tonach) & 1985 & 2333 \\
\hline Sery dojrzewające (w tonach) & 2343 & 229 \\
\hline Sery topione (w tonach) & 314 & 15 \\
\hline Napoje ferment. (w tys. litrów) & 449,5 & 1027,9 \\
\hline Mleko w proszku (w tonach) & 1807 & 3446 \\
\hline Kazeina (w tonach) & 369 & 0 \\
\hline
\end{tabular}

Źródło: Materiały statystyczne WUS, Słupsk 1996

Podstawowym produktem wytwarzanym przez wszystkie mleczarnie było spożywcze mleko homogenizowane. Jego produkcja w 1990 r. wyniosła 26798 tys. 1, co stanowiło $22,1 \%$ ogólnej ilości mleka skupionego i zagospodarowanego przez zakłady mleczarskie. W roku 1991 nastąpił gwałtowny spadek tej produkcji aż o 45,9\%, który został wyhamowany w kolejnych latach. Od 1995 r. obserwuje się stopniowy wzrost produkcji, co jest między innymi wynikiem zwiększonego zapotrzebowania na mleko wskutek zmian relacji cen mleka do produktów mięsnych, a także poprawy jego jakości i rozszerzenia oferty gatunkowej. W 1996 r. zakłady mleczarskie przygotowały dla konsumentów ogółem 13,5 mln litrów mleka spożywczego. 
Kolejnym znaczącym produktem przemysłu mleczarskiego jest mleko w proszku, którego wyprodukowano 1807 t w 1990 r., a w 1995 r. już 3446 t. Wyraźny wzrost produkcji tego wyrobu o blisko $1640 \mathrm{t}$, tj. o 90,0\%, spowodowany jest dość dobrą koniunkturą cenową na rynkach europejskich, nowoczesną linią technologiczną o dużej mocy przerobowej w Zakładzie „Nestlé”, a także rozpoczęciem na jego bazie produkcji odżywek dla dzieci przez ten zakład (Owsiany 1997). 
Ryc. 6. Produkcja wyrobów mleczarskich w województwie słupskim w latach 1990-1995

Istotny wzrost produkcji cechuje także napoje fermentowane (a zwłaszcza jogurty), co jest wynikiem znacznego wzrostu popytu na te towary i atrakcyjnej oferty gatunkowej.

Na przestrzeni lat 1990-1995 spadła natomiast znacznie produkcja masła, serów dojrzewających i topionych. Wielkość produkcji masła pozostaje $\mathrm{w}$ ścisłej zależności z produkcją mleka, a jej spadek wynika także z preferencji społeczeństwa dla mniej kalorycznego żywienia. Spadek produkcji serów był skutkiem zmniejszenia ich spożycia przez ludność

w wyniku napływu konkurencyjnych, bardziej urozmaiconych i o lepszej jakości produktów tej grupy z mleczarni innych województw a także z zagranicy.

$\mathrm{Na}$ zakończenie chcemy podkreślić, że przemysł mleczarski w województwie słupskim jest ściśle związany ze specyficznymi uwarunkowaniami ekonomicznymi i rolniczymi

regionu. Województwo słupskie, charakteryzujące się do niedawna na tle kraju dużym udziałem sektora państwowego w rolnictwie (około 59,0\% powierzchni użytków rolnych), szczególnie dotkliwie odczuło efekty polityki gospodarczej początku lat 90. Duża liczba nieefektywnych państwowych gospodarstw rolnych nie mogła w szybkim tempie zaadaptować się do nowej rzeczywistości gospodarczej, wskutek czego ulegały one likwidacji lub głębokim przekształceniom. W lepszej sytuacji znalazły się gospodarstwa indywidualne, które nie zaciągały zbyt wielu kredytów, dzięki czemu zadłużenie nie było ich największym problemem. Głównym utrudnieniem natomiast stało się dla nich duże obniżenie realnej wartości cen skupu i nieterminowa zapłata za produkty (szczególnie często stosowana przez mleczarnie).

Podkreślić należy, że w latach 1990-1996 nastąpiły również bardzo duże zmiany w sektorze przetwórstwa mleka. W ciągu kilku lat zakłady mleczarskie zetknęły się z szeregiem niekorzystnych czynników: brakiem surowca, barierą popytu, konkurencją wyrobów zachodnich, zaprzestaniem dotacji. Mimo tego wszystkie istniejące w województwie słupskim mleczarnie przetrwały ten burzliwy okres, usamodzielniły się, wybierając własną drogę rozwoju. Obecnie o rozmiarach produkcji decyduje głównie rynek konsumentów, wobec czego zakłady muszą ciagle pracować nad obniżeniem kosztów wytwarzania, polepszeniem jakości i urozmaiceniem oferty towarowej.

Okres transformacji gospodarczej, mimo wielu negatywnych zjawisk, które mu towarzyszyły, można jednak uznać za przełomowy i potrzebny dla kształtowania się nowego rynku mlecznego w województwie słupskim. Nowy system gospodarczy pozwala na budowanie pożądanych powiązań między producentem mleka, zakładem przetwórczym i kon- 
sumentem, które w przyszłości, jak sądzimy, będą procentować wzrostem efektywności gospodarowania. Rozwój przetwórstwa mleka w najbliższych latach będzie zależeć głównie od dostępności do surowca i zapotrzebowania rynku na produkty mleczarskie, a także ich konkurencyjności w zetknięciu z wyrobami produkowanymi w innych regionach.

\section{Literatura}

Dziadek S., 1996, Przemiany więzi produkcyjno-przestrzennych w procesie przechodzenia do gospodarki rynkowej w Makroregionie Południowym, [w:] Wpływ procesów transformacji gospodarki narodowej na funkcjonowanie jednostek gospodarczych i układów przestrzennych, red. Z. Zioło, Kom. Geografii Przemysłu PTG i WSP w Krakowie, Kraków - Warszawa.

Górz B., Rajman J., 1995, Społeczno-ekonomiczne skutki restrukturyzacji gospodarki na przykładach z Poludniowej Polski (problemy metodyczne badań), [w:] Zadania badawcze geografii społeczno-ekonomicznej w obliczu transformacji ustrojowej i restrukturyzacji gospodarki (materiaty $z$ konferencji), pod red. A. Jagielskiego, Wrocław.

Program restrukturyzacji i modernizacji mleczarstwa w woj. stupskim, 1995, UW Słupsk.

Owsiany Z., 1997, „Zmiany na rynku mleka w województwie słupskim w latach 1990-1995”, praca magisterska przygotowana pod kier. E. Rydza, WSP Słupsk.

Rajman J., 1962, Rozwój ośrodków przemysłowych nad Matq Panwiq, Katowice.

Rydz E., Jażewicz I., 1994, Przemiany struktur przestrzenno-gatęziowych przemystu województwa stupskiego $w$ zmieniajacych się warunkach gospodarowania, [w:] Zachowania przestrzenne przemystu $w$ zmieniajacych się warunkach gospodarowania, red. Z. Zioło, Kraków - Warszawa.

Rydz E., Zaleski J., 1992, Rola i funkcje Stupska na tle sieci osadniczej Środkowego Wybrzeża, WSP Słupsk.

Zioło Z., 1996, Oddziatywanie procesów transformacji gospodarki narodowej na funkcjonowanie jednostek gospodarczych, [w:] Wplyw procesów transformacji gospodarki na funkcjonowanie jednostek gospodarczych i układów przestrzennych, red. Z. Zioło, Kom. Geografii Przemysłu PTG i WSP w Krakowie, Warszawa - Kraków. 